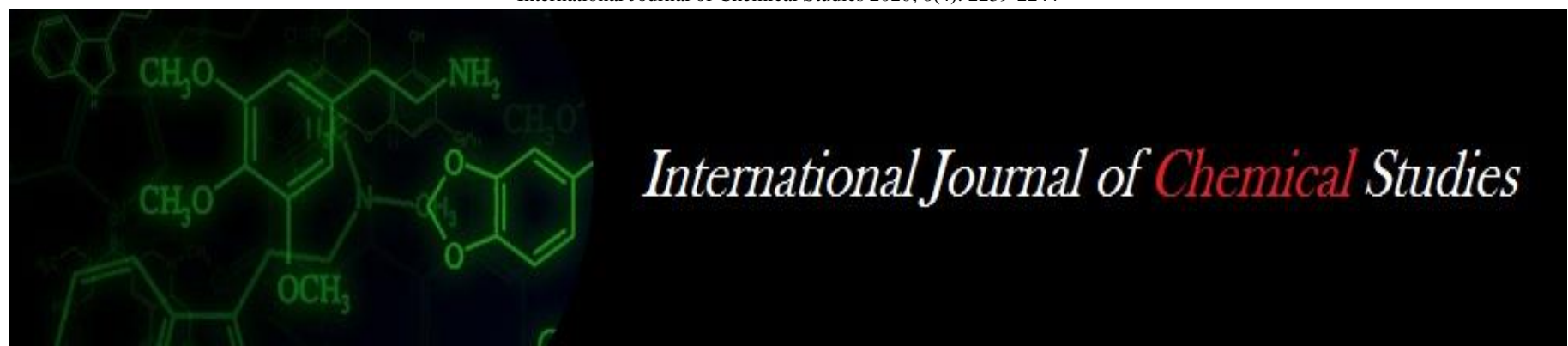

P-ISSN: 2349-8528

E-ISSN: 2321-4902

www.chemijournal.com

IJCS 2020; 8(4): 2239-2244

(C) 2020 IJCS

Received: 08-05-2020

Accepted: 10-06-2020

\section{Khadadiya MB}

Department of Agronomy, N. M. College of Agriculture, Navsari Agricultural University, Navsari, Gujarat, India

Patel AP

Department of Agronomy, N. M College of Agriculture, Navsari

Agricultural University, Navsari, Gujarat, India

\section{Desai NB}

Department of Agronomy, N. M. College of Agriculture, Navsari

Agricultural University, Navsari, Gujarat, India

\section{Patel UJ}

Department of Agronomy, N. M. College of Agriculture, Navsari Agricultural University, Navsari, Gujarat, India

Corresponding Author: Khadadiya MB

Department of Agronomy, N. M. College of Agriculture, Navsari Agricultural University, Navsari, Gujarat, India

\section{Effect of integrated nutrient management on content, uptake and quality of summer pearlmillet (Pennisetum glaucum L.) under south Gujarat condition}

\author{
Khadadiya MB, Patel AP, Desai NB and Patel UJ
}

DOI: https://doi.org/10.22271/chemi.2020.v8.i4y.9961

\begin{abstract}
A field experiment was conducted during summer season of 2018 at Collage Farm, N. M. Collage of Agriculture University, Navsari, Gujarat, to study the effect of integrated nutrient management on summer pearl millet under south Gujarat condition. Two levels of manure (no compost and vermicompost @ 10 t/ha), three fertilizer levels (no RDF, 75 per cent RDF and 100 per cent RDF) and two levels of biofertilizer (no seed inoculation and seed inoculation with Azotobacter @ 2 ml $/ \mathrm{kg}$ seeds) were compared. Application of 10 tonnes vermicompost/ha recorded significantly higher nutrient $(\mathrm{N}$, $\mathrm{P}_{2} \mathrm{O}_{5}$ and $\mathrm{K}_{2} \mathrm{O}$ ) content, uptake, protein content and protein yield over control. Improvement in nutrient content, uptake, protein content and protein yield were also noticed with 100 per cent RDF. Seed inoculation with Azotobacter also increased nutrient content, uptake, protein content and protein yield of pearlmillet over control.
\end{abstract}

Keywords: Vermicompost, pearlmillet, biofertilizer

\section{Introduction}

Pearlmillet (Pennisetum glaucum L.) is one of the important millet crops of India. Among the millets, it comes next to sorghum in area and production. Rajasthan ranks first in area and production of pearlmillet. Besides being a staple diet of about 10 per cent population of our country, it is an important fodder crop also. It is the only cereal crop that is capable of producing a reliable yield under the marginal environments and simultaneously responds to high management conditions. Its nutritious grain forms the important component of human diet and stover forms the principal maintenance ration for ruminant livestock during the dry poultry. It is nutritionally better than many cereals as it is a good source of protein (12.6 per cent), minerals, particularly iron ( 2.8 per cent) and fat ( 5 per cent). In India, it is annually grown on 8.74 million ha area producing nearly 8.83 million tonnes of grains with productivity of $1011 \mathrm{~kg} / \mathrm{ha}$ (Anon., 2011) ${ }^{[1]}$.

\section{Material and Methods}

In order to accomplish the objectives, the present field experiment entitled, "Effect of integrated nutrient management in summer pearlmillet (Pennisetum glaucum L.) under south Gujarat condition" was conducted during summer season of 2018 at the College Farm, N. M. College of Agriculture, Navsari Agricultural University, Navsari. The campus is geographically located at $20^{\circ}-57^{\prime} \mathrm{N}$ latitude and $72^{\circ}-54^{\prime} \mathrm{E}$ longitude at an altitude of 10 meters above the mean sea level. According to agro-climatic conditions, Navsari is located in south Gujarat heavy rainfall zone-I (Agro-ecological situation-III). The climate of this zone is typically tropical, characterized by humid and warm monsoon with heavy rain, quite cold winter and fairly hot summer. The average annual rainfall of the tract is about $1500 \mathrm{~mm}$. The soil of experimental field was clayey in texture, having $\mathrm{pH} 7.8$ with normal electrical conductivity $\left(0.36 \mathrm{dsm}^{-1}\right)$, low in organic carbon content $(0.72 \%)$, low in available nitrogen $\left(150.23 \mathrm{~kg} \mathrm{ha}^{-1}\right)$, medium in available phosphorus (49 $\left.\mathrm{kg} \mathrm{ha}^{-1}\right)$ and fairly rich in available potassium $\left(307.81 \mathrm{~kg} \mathrm{ha}^{-1}\right)$. 
The treatments consisted of two levels of manure (no compost and vermicompost @ $10 \mathrm{t} / \mathrm{ha}$ ), three fertilizer levels (no RDF, 75 per cent RDF and 100 per cent RDF) and two levels of biofertilizer (no seed inoculation and seed inoculation with Azotobacter @ $2 \mathrm{ml} / \mathrm{kg}$ seeds). These treatments were evaluated in randomized block design with factorial concept (FRBD) and replicate three times. Pearlmillet variety GCH732 was sown in furrows at $45 \mathrm{~cm}$ row spacing using a seed rate of $3.75 \mathrm{~kg} / \mathrm{ha}$. Application of fertilizers (120:60:00 NPK $\mathrm{kg} / \mathrm{ha}$ ) was applied as per treatment. Half dose of $\mathrm{N}$ and full dose of $\mathrm{P}$ and $\mathrm{K}$ applied basal at the time of sowing and remaining half dose of $\mathrm{N}$ at 30 and 60 days after sowing. Vermicompost $(1.74 \% \mathrm{~N}, 0.89 \% \mathrm{P}, 0.86 \% \mathrm{~K}$ and $12: 1 \mathrm{C}: \mathrm{N}$ ration) was mixed in soil at the time of field preparation as per treatment. Seed was uniformly coated with Azotobacter @ 2 $\mathrm{ml} / \mathrm{kg}$ seeds as per treatments. The results were analysed using standard statistical procedure given by Panse and Sukhatme (1985) ${ }^{[13]}$.

\section{Result and Discussion \\ Effect of Manure}

Significant effect of vermicompost was observed on content, uptake and quality of pearlmillet. A significant increase in concentration of $\mathrm{N}, \mathrm{P}_{2} \mathrm{O}_{5}$ and $\mathrm{K}_{2} \mathrm{O}$ in grain $(1.83,0.33$ per cent and 0.65 per cent, respectively) and straw $(0.66,0.17$ per cent and 0.99 per cent, respectively) of pearlmillet was observed due to application of vermicompost @ 10 t/ha. The application of manures significantly increased the concentration $\left(\mathrm{N}, \mathrm{P}_{2} \mathrm{O}_{5}\right.$ and $\left.\mathrm{K}_{2} \mathrm{O}\right)$ in grain and straw. It can chiefly be associated with the better growth of the crop due to favorable nutritional environment mainly for supply of most of the macro and micro nutrients in balanced and available form throughout the growing period of the crop and in adequate amounts.

Since, the significantly highest $\mathrm{N}, \mathrm{P}_{2} \mathrm{O}_{5}$ and $\mathrm{K}_{2} \mathrm{O}$ uptake of nutrients in grain $(92.72,16.96 \mathrm{~kg} / \mathrm{ha}$ and $33.15 \mathrm{~kg} / \mathrm{ha}$, respectively), straw $(73.75,19.71 \mathrm{~kg} / \mathrm{ha}$ and $112.10 \mathrm{~kg} / \mathrm{ha}$, respectively) and total uptake of $\mathrm{N}, \mathrm{P}_{2} \mathrm{O}_{5}$ and $\mathrm{K}_{2} \mathrm{O}$ by grain and straw (166.48, 36.68 and $145.23 \mathrm{~kg} / \mathrm{ha}$, respectively) was recorded in application of vermicompost @ $10 \mathrm{t} / \mathrm{ha}\left(\mathrm{M}_{2}\right)$

The uptake is a function of their concentration and yield, the increase in grain and straw yield coupled with increased nutrient concentration also resulted in higher uptake of nitrogen, phosphorus and potassium with the application of vermicompost @ $10 \mathrm{t} / \mathrm{ha}$. Use of organic manures (vermicompost) has also been known to help in reducing the soil $\mathrm{pH}$ to some extent by producing organic acids while their decomposition that may also be the reason of greater availability and mobility of nutrients mainly of micronutrients. This could have also helped in additional uptake of the nutrients by plants. The findings of the present investigation are in agreement with those of Kathuria et al. (2003) ${ }^{[8]}$ in pearlmillet, Kumawat and Jat (2005) ${ }^{[9]}$ in barley and Vandana et al. (2008) ${ }^{[19]}$ in pearlmillet and Jadhav et al. $(2011)^{[6]}$ in pearlmillet.

Protein content and protein yield was significantly influenced due to manure. Vermicompost @ 10 t/ha recorded higher value of protein content (11.43 per cent) and protein yield $(579.57 \mathrm{~kg} / \mathrm{ha})$ in grain of pearlmillet as compared to no compost. The increase in protein content and protein yield was ascribed to the fact that the protein content and protein yield in grain is infect a manifestation of nitrogen concentration in grain as discussed in nutrient content and uptake. The increased concentration of nitrogen in grain directly resulted in high protein content recorded with application of vermicompost $10 \mathrm{t} / \mathrm{ha}$ in comparison to no compost. The findings of the present investigation are in agreement with those of Vidyadharan (2008) ${ }^{[20]}$ in barley and Jadhav et al. $(2011)^{[6]}$ in pearlmillet.

\section{Effect of fertilizer}

$\mathrm{N}, \mathrm{P}_{2} \mathrm{O}_{5}$ and $\mathrm{K}_{2} \mathrm{O}$ content and uptake of grain and straw were influenced by fertilizer application. Significantly higher N, $\mathrm{P}_{2} \mathrm{O}_{5}$ and $\mathrm{K}_{2} \mathrm{O}$ content in grain $(1.76,0.31$ per cent and 0.65 per cent, respectively) was recorded with application of 100 per cent RDF $\left(\mathrm{F}_{3}\right)$. The significantly lowest $\mathrm{N}, \mathrm{P}_{2} \mathrm{O}_{5}$ and $\mathrm{K}_{2} \mathrm{O}$ content in grain registered with application of no $\mathrm{RDF}\left(\mathrm{F}_{1}\right)$. Significantly higher $\mathrm{N}, \mathrm{P}_{2} \mathrm{O}_{5} \mathrm{O}$ and $\mathrm{K}_{2} \mathrm{O}$ content in straw ( 0.61 , 0.17 per cent and 0.95 per cent, respectively) was recorded with application of 100 per cent RDF (F3). The significantly lowest $\mathrm{N}, \mathrm{P}_{2} \mathrm{O}_{5}$ and $\mathrm{K}_{2} \mathrm{O}$ content in straw registered with application of no RDF $\left(\mathrm{F}_{1}\right)$.

The $\mathrm{N}, \mathrm{P}_{2} \mathrm{O}_{5}$ and $\mathrm{K}_{2} \mathrm{O}$ uptake by grain $(77.82,14.11 \mathrm{~kg} / \mathrm{ha}$ and $28.43 \mathrm{~kg} / \mathrm{ha}$, respectively) was recorded significantly higher with application of 100 per cent $\mathrm{RDF}\left(\mathrm{F}_{3}\right)$. The significantly lowest $\mathrm{N}, \mathrm{P}_{2} \mathrm{O}_{5}$ and $\mathrm{K}_{2} \mathrm{O}$ uptake by grain $(42.16,7.35 \mathrm{~kg} / \mathrm{ha}$ and $14.59 \mathrm{~kg} / \mathrm{ha}$ ) registered with application of no $\mathrm{RDF}\left(\mathrm{F}_{1}\right)$.

Significantly higher $\mathrm{N}, \mathrm{P}_{2} \mathrm{O}_{5}$ and $\mathrm{K}_{2} \mathrm{O}$ uptake by straw (60.46, $18.86 \mathrm{~kg} / \mathrm{ha}$ and $94.44 \mathrm{~kg} / \mathrm{ha}$, respectively) and total uptake of $\mathrm{N}, \mathrm{P}_{2} \mathrm{O}_{5}$ and $\mathrm{K}_{2} \mathrm{O}$ by grain and straw $(138.28,30.97$ and $122.87 \mathrm{~kg} / \mathrm{ha}$, respectively) was recorded with application of 100 per cent $\mathrm{RDF}\left(\mathrm{F}_{3}\right)$. The significantly lowest $\mathrm{N}, \mathrm{P}_{2} \mathrm{O}_{5}$ and $\mathrm{K}_{2} \mathrm{O}$ uptake by straw $(34.98,8.44 \mathrm{~kg} / \mathrm{ha}$ and $47.02 \mathrm{~kg} / \mathrm{ha}$ ) was registered with application of no $\operatorname{RDF}\left(\mathrm{F}_{1}\right)$. The higher removal of $\mathrm{N}, \mathrm{P}_{2} \mathrm{O}_{5}$ and $\mathrm{K}_{2} \mathrm{O}$ with this level might be due to better development of root and shoot resulted in higher $\mathrm{N}$, $\mathrm{P}_{2} \mathrm{O}_{5}$ and $\mathrm{K}_{2} \mathrm{O}$ uptake. These findings were supported by Rathore et al. (2006) ${ }^{[14]}$, Narolia and Poonia (2011) ${ }^{[12]}$, Shrivastava and Arya (2017) ${ }^{[15]}$ in pearlmillet and Duhan (2013) ${ }^{[4]}$ in sorghum.

The quality parameters viz., protein content and protein yield in grain significantly due to fertilizer application in pearlmillet. However, numerically higher protein content (10.97 per cent) and yield $(486.38 \mathrm{~kg} / \mathrm{ha})$ in grain was recorded higher in treatment 100 per cent $\operatorname{RDF}\left(\mathrm{F}_{3}\right)$. The significantly lowest protein content and yield in grain registered with application of no $\mathrm{RDF}\left(\mathrm{F}_{1}\right)$. These findings are in close conformity wi th those of Tripathi and Kushwaha (2013) ${ }^{[18]}$, Chanrda et al. (2014) ${ }^{[3]}$ in pearlmillet, Gangwar and Niranjan (1991) ${ }^{[5]}$ in fodder sorghum.

\section{Effect of biofertilizer}

Seed inoculation with Azotobacter significantly enhanced N, $\mathrm{P}_{2} \mathrm{O}_{5}$ and $\mathrm{K}_{2} \mathrm{O}$ concentration in grain $(1.76,0.31$ per cent and 0.63 per cent, respectively) and straw $(0.60,0.17$ per cent and 0.91 per cent, respectively) and $\mathrm{N}, \mathrm{P}_{2} \mathrm{O}_{5}$ and $\mathrm{K}_{2} \mathrm{O}$ uptake in grain $(70.71,12.73 \mathrm{~kg} / \mathrm{ha}$ and $25.50 \mathrm{~kg} / \mathrm{ha}$, respectively), straw $(54.99,15.46 \mathrm{~kg} / \mathrm{ha}$ and $83.79 \mathrm{~kg} / \mathrm{ha}$, respectively) and total uptake of $\mathrm{N}, \mathrm{P}_{2} \mathrm{O}_{5}$ and $\mathrm{K}_{2} \mathrm{O}$ by grain and straw (125.70, 28.19 and $109.29 \mathrm{~kg} / \mathrm{ha}$, respectively) over without inoculation. The concentration and uptake of any nutrient in the plant is directly related to its availability in the root zone and growth of the plant. Use of Azotobacter significantly increased the $\mathrm{N}, \mathrm{P}_{2} \mathrm{O}_{5}$ and $\mathrm{K}_{2} \mathrm{O}$ concentration in grain and straw that might mainly be attributed to their availability in soil in appreciable amount and in the available form due to this microbial inoculant. It also promotes secretion of growth promoting substances which also resulted in better utilization of other nutrients like $\mathrm{P}_{2} \mathrm{O}_{5}$ by plants. The greater uptake of $\mathrm{N}, \mathrm{P}_{2} \mathrm{O}_{5}$ and $\mathrm{K}_{2} \mathrm{O}$ are directly related with the increased 
concentration of these nutrients in seed and straw and significantly higher seed and straw yields observed under inoculation of seed with Azotobacter treatment than without inoculation. These results also corroborate with the findings of Wani et al. (1998) ${ }^{[21]}$, Togas et al. (2015) ${ }^{[17]}$ in pearlmillet. Protein content and protein yield was significantly influenced due to biofertilizer. Seed inoculation with Azotobacter recorded higher value of protein content (10.99 per cent) and protein yield $(441.97 \mathrm{~kg} / \mathrm{ha})$ in grain of pearlmillet as compared to no seed inoculation. The increase in protein content and protein yield was ascribed to the fact that the protein content and protein yield in grain is infect a manifestation of nitrogen concentration in grain as discussed in nutrient content and uptake. The increased concentration of nitrogen in grain directly resulted in high protein content recorded with application of seed inoculation with Azotobacter in comparison to no seed inoculation. The findings of the present investigation are in agreement with those of Nanda et al. (2001) ${ }^{[11]}$ in sorghum and Suke et al. $(2011)^{[16]}$ in sorghum.

\section{Interaction effect}

$\mathrm{N}, \mathrm{P}_{2} \mathrm{O}_{5}$ uptake by grain and $\mathrm{P}_{2} \mathrm{O}_{5}$ uptake by straw was significantly influenced by interaction effect of manure and fertilizer ( $\mathrm{M} \times \mathrm{F})$. It was also significantly influenced due to manure and biofertilizer ( $\mathrm{M} \times \mathrm{B})$. The treatment combination remarkably increased the $\mathrm{N}, \mathrm{P}_{2} \mathrm{O}_{5}$ uptake by grain (111.16 $\mathrm{kg} / \mathrm{ha}$ and $20.81 \mathrm{~kg} / \mathrm{ha})$ and $\mathrm{P}_{2} \mathrm{O}_{5}$ uptake by straw $(24.43$ $\mathrm{kg} / \mathrm{ha}$ ) and noted higher under $\mathrm{M}_{2} \mathrm{~F}_{3}$ (Vermicompost @ 10 t/ha +100 per cent $\mathrm{RDF}$ ). Maximum $\mathrm{N}, \mathrm{P}_{2} \mathrm{O}_{5}$ uptake by grain (101.91 kg/ha and $18.84 \mathrm{~kg} / \mathrm{ha}$ ) and $\mathrm{P}_{2} \mathrm{O}_{5}$ uptake by straw $(22.55 \mathrm{~kg} / \mathrm{ha})$ were produced under treatment combination of $\mathrm{M}_{2} \mathrm{~B}_{2}$ (Vermicompost @ $10 \mathrm{t} / \mathrm{ha}+$ seed inoculation with Azotobacter).

$\mathrm{K}_{2} \mathrm{O}$ uptake by grain and $\mathrm{N}, \mathrm{K}_{2} \mathrm{O}$ uptake by straw was significantly persuaded due to interaction effect of manure and fertilizer $(\mathrm{M} \times \mathrm{F})$. The treatment combination of $\mathrm{M}_{2} \mathrm{~F}_{3}$
(Vermicompost@10 t/ha + 100 per cent RDF) showed higher effect on $\mathrm{K}_{2} \mathrm{O}$ uptake by grain $(40.13 \mathrm{~kg} / \mathrm{ha})$ and $\mathrm{N}$, $\mathrm{K}_{2} \mathrm{O}$ uptake by straw $(86.83 \mathrm{~kg} / \mathrm{ha}$ and $135.81 \mathrm{~kg} / \mathrm{ha})$.

Total uptake of $\mathrm{N}, \mathrm{P}_{2} \mathrm{O}_{5}$ and $\mathrm{K}_{2} \mathrm{O}$ by grain and straw was significantly influenced by interaction effect of manure and fertilizer ( $\mathrm{M} \times \mathrm{F}$ ). It was also significantly influenced due to manure and biofertilizer ( $\mathrm{M} \times \mathrm{B})$. The treatment combination remarkably increased the total uptake of $\mathrm{N}, \mathrm{P}_{2} \mathrm{O}_{5}$ and $\mathrm{K}_{2} \mathrm{O}$ by grain and straw (197.99, 45.24 and $176.04 \mathrm{~kg} / \mathrm{ha})$ noted higher under $\mathrm{M}_{2} \mathrm{~F}_{3}$ (Vermicompost @ 10 t/ha +100 per cent $\mathrm{RDF}$ ). Maximum total uptake of $\mathrm{N}, \mathrm{P}_{2} \mathrm{O}_{5}$ and $\mathrm{K}_{2} \mathrm{O}$ by grain and straw $(181.24,41.39$ and $158.44 \mathrm{~kg} / \mathrm{ha}$ ) were produced under treatment combination of $\mathrm{M}_{2} \mathrm{~B}_{2}$ (Vermicompost @ 10 t/ha + seed inoculation with Azotobacter). Since, the uptake of nutrients in grain and straw is a function of their concentration and yield, the increase in grain and straw yield coupled with increased nutrient concentration also resulted in higher total uptake of $\mathrm{N}, \mathrm{P}_{2} \mathrm{O}_{5}$ and $\mathrm{K}_{2} \mathrm{O}$ with the application of $\mathrm{M}_{2} \mathrm{~F}_{3}$. Bhalerao et al. (2002) ${ }^{[2]}$ in sorghum and Jain et al. (2018) ${ }^{[7]}$ in pearlmillet also reported similar results.

Protein yield was significantly influenced by interaction effect of manure and fertilizer ( $\mathrm{M}$ x F). It was also significantly influenced due to manure and biofertilizer ( $\mathrm{M} \times \mathrm{B}$ ). The treatment combination remarkably increased the protein yield $\left(694.78 \mathrm{~kg} / \mathrm{ha}\right.$ ) and noted higher under $\mathrm{M}_{2} \mathrm{~F}_{3}$ (Vermicompost @ $10 \mathrm{t} / \mathrm{ha}+100$ per cent RDF). Maximum number of protein yield $(636.91 \mathrm{~kg} / \mathrm{ha})$ were produced under treatment combination of $\mathrm{M}_{2} \mathrm{~B}_{2}$ (Vermicompost @ $10 \mathrm{t} / \mathrm{ha}+$ seed inoculation with Azotobacter). The increase in protein yield was ascribed to the fact that the protein yield in grain is infect a manifestation of nitrogen concentration in grain as discussed in nutrient content and uptake. The increased concentration of nitrogen in grain directly resulted in high protein yield recorded with application of $\mathrm{M}_{2} \mathrm{~F}_{3}$. These results supported the observation made by Bhalerao et al. (2002) ${ }^{[2]}$ in sorghum and Lattief (2011) ${ }^{[10]}$ in pearlmillet.

Table 1: $\mathrm{N}, \mathrm{P}_{2} \mathrm{O}_{5}$ and $\mathrm{K}_{2} \mathrm{O}$ content in grain and straw of pearlmillet as influenced by integrated nutrient management

\begin{tabular}{|c|c|c|c|c|c|c|}
\hline \multirow{2}{*}{ Treatments } & \multicolumn{3}{|c|}{ Nutrient content in grain $(\%)$} & \multicolumn{3}{|c|}{ Nutrient content in straw $(\%)$} \\
\hline & $\mathbf{N}$ & $\mathrm{P}_{2} \mathrm{O}_{5}$ & $\mathbf{K}_{2} \mathbf{O}$ & $\mathbf{N}$ & $\mathbf{P}_{2} \mathrm{O}_{5}$ & $\mathrm{~K}_{2} \mathrm{O}$ \\
\hline \multicolumn{7}{|c|}{ (A) Manure (M) } \\
\hline No compost $\left(\mathrm{M}_{1}\right)$ & 1.58 & 0.26 & 0.56 & 0.52 & 0.13 & 0.76 \\
\hline Vermicompost @ 10 t/ha $\left(\mathrm{M}_{2}\right)$ & 1.83 & 0.33 & 0.65 & 0.66 & 0.17 & 0.99 \\
\hline S.Em. \pm & 0.02 & 0.004 & 0.01 & 0.01 & 0.002 & 0.01 \\
\hline C.D. at $5 \%$ & 0.05 & 0.01 & 0.03 & 0.03 & 0.01 & 0.04 \\
\hline \multicolumn{7}{|c|}{ (B) Fertilizer (F) } \\
\hline No RDF $\left(F_{1}\right)$ & 1.62 & 0.27 & 0.56 & 0.54 & 0.13 & 0.75 \\
\hline 75 per cent $\mathrm{RDF}\left(\mathrm{F}_{2}\right)$ & 1.75 & 0.30 & 0.61 & 0.61 & 0.16 & 0.92 \\
\hline 100 Per cent RDF $\left(\mathrm{F}_{3}\right)$ & 1.76 & 0.31 & 0.65 & 0.61 & 0.17 & 0.95 \\
\hline S.Em. \pm & 0.02 & 0.005 & 0.01 & 0.01 & 0.003 & 0.02 \\
\hline C.D. at $5 \%$ & 0.06 & 0.02 & 0.03 & 0.03 & 0.01 & 0.04 \\
\hline \multicolumn{7}{|c|}{ (C) Biofertilizer (B) } \\
\hline No seed inoculation $\left(\mathrm{B}_{1}\right)$ & 1.65 & 0.28 & 0.58 & 0.57 & 0.14 & 0.84 \\
\hline Seed inoculation with Azotobacter $\left(\mathrm{B}_{2}\right)$ & 1.76 & 0.31 & 0.63 & 0.60 & 0.17 & 0.91 \\
\hline S.Em. \pm & 0.02 & 0.004 & 0.01 & 0.01 & 0.002 & 0.01 \\
\hline C.D. at $5 \%$ & 0.05 & 0.01 & 0.03 & 0.03 & 0.01 & 0.04 \\
\hline
\end{tabular}


Table 2: $\mathrm{N}, \mathrm{P}_{2} \mathrm{O}_{5}$ and $\mathrm{K}_{2} \mathrm{O}$ uptake by grain and straw of pearlmillet as influenced by integrated nutrient management

\begin{tabular}{|c|c|c|c|c|c|c|}
\hline \multirow{2}{*}{ Treatments } & \multicolumn{3}{|c|}{ Nutrient uptake by grain (kg/ha) } & \multicolumn{3}{|c|}{ Nutrient uptake by straw (kg/ha) } \\
\hline & $\mathbf{N}$ & $\mathbf{P}_{2} \mathrm{O}_{5}$ & $\mathbf{K}_{2} \mathbf{O}$ & $\mathbf{N}$ & $\mathbf{P}_{2} \mathrm{O}_{5}$ & $\mathrm{~K}_{2} \mathrm{O}$ \\
\hline \multicolumn{7}{|c|}{ (A) Manure (M) } \\
\hline No compost $\left(\mathrm{M}_{1}\right)$ & 35.56 & 5.81 & 12.65 & 28.00 & 7.21 & 41.62 \\
\hline Vermicompost @ 10 t/ha $\left(\mathrm{M}_{2}\right)$ & 92.72 & 16.96 & 33.15 & 73.75 & 19.71 & 112.10 \\
\hline S.Em. \pm & 1.32 & 0.33 & 0.62 & 1.66 & 0.39 & 2.20 \\
\hline C.D. at $5 \%$ & 3.88 & 0.97 & 1.82 & 4.87 & 1.15 & 6.46 \\
\hline \multicolumn{7}{|c|}{ (B) Fertilizer (F) } \\
\hline No RDF $\left(F_{1}\right)$ & 35.56 & 5.81 & 12.65 & 34.98 & 8.44 & 47.02 \\
\hline 75 per cent $\mathrm{RDF}\left(\mathrm{F}_{2}\right)$ & 92.72 & 16.96 & 33.15 & 57.19 & 15.08 & 88.09 \\
\hline 100 Per cent RDF $\left(\mathrm{F}_{3}\right)$ & 1.32 & 0.33 & 0.62 & 60.46 & 16.86 & 94.44 \\
\hline S.Em. \pm & 3.88 & 0.97 & 1.82 & 2.04 & 0.48 & 2.70 \\
\hline C.D. at $5 \%$ & 42.16 & 7.35 & 14.59 & 5.97 & 1.41 & 7.91 \\
\hline \multicolumn{7}{|c|}{ (C) Biofertilizer (B) } \\
\hline No seed inoculation $\left(\mathrm{B}_{1}\right)$ & 35.56 & 5.81 & 12.65 & 46.77 & 11.46 & 69.91 \\
\hline Seed inoculation with Azotobacter $\left(\mathrm{B}_{2}\right)$ & 92.72 & 16.96 & 33.15 & 54.99 & 15.46 & 83.79 \\
\hline S.Em. \pm & 1.32 & $\mathbf{0 . 3 3}$ & 0.62 & 1.66 & 0.39 & 2.20 \\
\hline C.D. at 5\% & 3.88 & 0.97 & 1.82 & 4.87 & 1.15 & 6.46 \\
\hline
\end{tabular}

Table 3: Total uptake of $\mathrm{N}, \mathrm{P}_{2} \mathrm{O}_{5}$ and $\mathrm{K}_{2} \mathrm{O}$ by grain and straw of pearlmillet as influenced by integrated nutrient management

\begin{tabular}{|c|c|c|c|}
\hline \multirow[t]{2}{*}{ Treatments } & \multicolumn{3}{|c|}{$\begin{array}{c}\text { Total nutrient uptake by grair } \\
\text { and straw }(\mathrm{kg} / \mathrm{ha})\end{array}$} \\
\hline & $\mathbf{N}$ & $\mathrm{P}_{2} \mathrm{O}_{5}$ & $\mathrm{~K}_{2} \mathrm{O}$ \\
\hline \multicolumn{4}{|c|}{ (A) Manure (M) } \\
\hline No compost $\left(\mathrm{M}_{1}\right)$ & 63.56 & 13.01 & 54.28 \\
\hline Vermicompost @ $10 \mathrm{t} / \mathrm{ha}\left(\mathrm{M}_{2}\right)$ & 166.48 & 36.68 & 145.23 \\
\hline S.Em. + & 2.23 & 0.59 & 2.37 \\
\hline C.D. at $5 \%$ & 6.55 & 1.72 & 6.96 \\
\hline \multicolumn{4}{|c|}{ (B) Fertilizer (F) } \\
\hline $\operatorname{No} \operatorname{RDF}\left(\mathrm{F}_{1}\right)$ & 77.14 & 15.78 & 62.62 \\
\hline 75 per cent $\mathrm{RDF}\left(\mathrm{F}_{2}\right)$ & 129.64 & 27.78 & 113.77 \\
\hline 100 Per cent $\mathrm{RDF}\left(\mathrm{F}_{3}\right)$ & 138.28 & 30.97 & 122.87 \\
\hline S.Em. + & 2.74 & 0.72 & 2.91 \\
\hline C.D. at $5 \%$ & 8.03 & 2.11 & 8.52 \\
\hline \multicolumn{4}{|c|}{ (C) Biofertilizer (B) } \\
\hline No seed inoculation $\left(\mathrm{B}_{1}\right)$ & 104.34 & 21.50 & 90.21 \\
\hline $\begin{array}{l}\text { Seed inoculation with } \\
\text { Azotobacter }\left(\mathrm{B}_{2}\right)\end{array}$ & 125.70 & 28.19 & 109.29 \\
\hline S.Em. + & 2.23 & 0.59 & 2.37 \\
\hline C.D. at $5 \%$ & 6.55 & 1.72 & 6.96 \\
\hline
\end{tabular}

Table 4: Protein content and protein yield in grain of pearlmillet as influenced by integrated nutrient management

\begin{tabular}{|c|c|c|}
\hline Treatments & $\begin{array}{c}\text { Protein } \\
\text { content } \\
(\%)\end{array}$ & $\begin{array}{c}\text { Protein } \\
\text { yield } \\
\text { (kg/ha) }\end{array}$ \\
\hline \multicolumn{3}{|l|}{ (A) Manure (M) } \\
\hline No compost $\left(\mathrm{M}_{1}\right)$ & 9.90 & 222.30 \\
\hline Vermicompost @ 10 t/ha $\left(\mathrm{M}_{2}\right)$ & 11.43 & 579.57 \\
\hline S.Em. + & 0.11 & 8.25 \\
\hline C.D. at $5 \%$ & 0.32 & 24.21 \\
\hline \multicolumn{3}{|l|}{ (B) Fertilizer $(\mathbf{F})$} \\
\hline No RDF $\left(F_{1}\right)$ & 10.11 & 263.52 \\
\hline 75 per cent $\mathrm{RDF}\left(\mathrm{F}_{2}\right)$ & 10.91 & 452.92 \\
\hline 100 Per cent $\mathrm{RDF}\left(\mathrm{F}_{3}\right)$ & 10.97 & 486.38 \\
\hline S.Em. + & 0.13 & 10.11 \\
\hline C.D. at $5 \%$ & 0.39 & 29.65 \\
\hline \multicolumn{3}{|l|}{ (C) Biofertilizer $(B)$} \\
\hline No seed inoculation $\left(\mathrm{B}_{1}\right)$ & 10.33 & 359.90 \\
\hline Seed inoculation with Azotobacter $\left(\mathrm{B}_{2}\right)$ & 10.99 & 441.97 \\
\hline S.Em. + & 0.11 & 8.25 \\
\hline C.D. at $5 \%$ & 0.32 & 24.20 \\
\hline
\end{tabular}

Table 5: Interaction effects on $\mathrm{N}$ uptake by grain of pearlmillet

\begin{tabular}{|c|c|c|c|c|c|}
\hline \multirow{3}{*}{$\begin{array}{l}\text { Treatments } \\
\text { Manure (M) } \\
\end{array}$} & \multicolumn{5}{|c|}{$\mathrm{N}$ uptake by grain (kg/ha) } \\
\hline & \multicolumn{3}{|c|}{ Fertilizer $(\mathbf{F})$} & \multicolumn{2}{|c|}{ Biofertilizer (B) } \\
\hline & $F_{1}$ & $\mathrm{~F}_{2}$ & $\mathrm{~F}_{3}$ & $\mathrm{~B}_{1}$ & $\mathrm{~B}_{2}$ \\
\hline $\mathrm{M}_{1}$ & 21.58 & 40.63 & 44.47 & 31.61 & 39.52 \\
\hline $\mathrm{M}_{2}$ & 62.73 & 104.27 & 111.16 & 83.54 & 101.91 \\
\hline S.Em. \pm & \multicolumn{3}{|c|}{2.29} & \multicolumn{2}{|c|}{1.87} \\
\hline C.D. at $5 \%$ & \multicolumn{3}{|c|}{6.72} & \multicolumn{2}{|c|}{5.48} \\
\hline
\end{tabular}

Table 6: Interaction effects on $\mathrm{P}_{2} \mathrm{O}_{5}$ uptake by grain of pearlmillet

\begin{tabular}{|c|c|c|c|c|c|}
\hline \multirow{3}{*}{$\begin{array}{l}\text { Treatments } \\
\text { Manure (M) } \\
\end{array}$} & \multicolumn{5}{|c|}{$\mathrm{P}_{2} \mathrm{O}_{5}$ uptake by grain $(\mathrm{kg} / \mathrm{ha})$} \\
\hline & \multicolumn{3}{|c|}{ Fertilizer $(\mathbf{F})$} & \multicolumn{2}{|c|}{ Biofertilizer (B) } \\
\hline & $\mathrm{F}_{1}$ & $\mathrm{~F}_{2}$ & $\mathrm{~F}_{3}$ & $\mathrm{~B}_{1}$ & $\mathrm{~B}_{2}$ \\
\hline $\mathrm{M}_{1}$ & 3.39 & 6.61 & 7.41 & 4.99 & 6.62 \\
\hline $\mathrm{M}_{2}$ & 11.30 & 18.78 & 20.81 & 15.09 & 18.84 \\
\hline S.Em. \pm & \multicolumn{3}{|c|}{0.57} & \multicolumn{2}{|c|}{0.47} \\
\hline C.D. at $5 \%$ & \multicolumn{3}{|c|}{1.67} & \multicolumn{2}{|c|}{1.37} \\
\hline
\end{tabular}


Table 7: Interaction effect on $\mathrm{K}_{2} \mathrm{O}$ uptake by grain of pearlmillet

\begin{tabular}{|c|c|c|c|}
\hline \multirow{2}{*}{ Treatments } & \multicolumn{3}{|c|}{$\mathbf{K}_{\mathbf{2}} \mathbf{O}$ uptake by grain (kg/ha) } \\
\cline { 2 - 4 } & \multicolumn{3}{|c|}{ Fertilizer (F) } \\
\hline Manure (M) & $\mathrm{F}_{1}$ & $\mathrm{~F}_{2}$ & $\mathrm{~F}_{3}$ \\
\hline $\mathrm{M}_{1}$ & 7.18 & 14.05 & 16.73 \\
\hline $\mathrm{M}_{2}$ & 21.10 & 37.31 & 40.13 \\
\hline S.Em. \pm & \multicolumn{3}{|c|}{1.08} \\
\hline C.D. at 5\% & 3.15 \\
\hline
\end{tabular}

Table 8: Interaction effect on $\mathrm{N}$ uptake by straw of pearlmillet

\begin{tabular}{|c|c|c|c|}
\hline \multirow{2}{*}{ Treatments } & \multicolumn{3}{|c|}{ N uptake by straw (kg/ha) } \\
\cline { 2 - 4 } & $\mathrm{F}_{1}$ & $\mathrm{~F}_{2}$ & $\mathrm{~F}_{3}$ \\
\hline Manure (M) & 18.01 & 31.91 & 34.08 \\
\hline $\mathrm{M}_{1}$ & 51.96 & 82.47 & 86.83 \\
\hline $\mathrm{M}_{2}$ & \multicolumn{3}{|c|}{2.88} \\
\hline S.Em. \pm & 8.44 \\
\hline C.D. at 5\% & \multicolumn{3}{|c}{} \\
\hline
\end{tabular}

Table 9: Interaction effects on $\mathrm{P}_{2} \mathrm{O}_{5}$ uptake by straw of pearlmillet

\begin{tabular}{|c|c|c|c|c|c|}
\hline \multirow{2}{*}{ Treatments } & \multicolumn{5}{|c|}{$\mathrm{P}_{2} \mathrm{O}_{5}$ uptake by straw (kg/ha) } \\
\hline & \multicolumn{3}{|c|}{ Fertilizer $(\mathbf{F})$} & \multicolumn{2}{|c|}{ Biofertilizer (B) } \\
\hline Manure (M) & $\mathrm{F}_{1}$ & $\mathrm{~F}_{2}$ & $\mathrm{~F}_{3}$ & $\mathrm{~B}_{1}$ & $\mathrm{~B}_{2}$ \\
\hline $\mathrm{M}_{1}$ & 4.06 & 8.27 & 9.29 & 6.05 & 8.37 \\
\hline $\mathrm{M}_{2}$ & 12.82 & 21.90 & 24.43 & 16.88 & 22.55 \\
\hline S.Em. \pm & \multicolumn{3}{|c|}{0.68} & \multicolumn{2}{|c|}{0.56} \\
\hline C.D. at 5\% & \multicolumn{3}{|c|}{1.20} & \multicolumn{2}{|c|}{1.63} \\
\hline
\end{tabular}

Table 10: Interaction effects on $\mathrm{K}_{2} \mathrm{O}$ uptake by straw of pearlmillet

\begin{tabular}{|c|c|c|c|}
\hline \multirow{2}{*}{ Treatments } & \multicolumn{3}{|c|}{$\mathbf{K}_{\mathbf{2}} \mathbf{O}$ uptake by straw (kg/ha) } \\
\cline { 2 - 4 } & \multicolumn{3}{|c|}{ Fertilizer (F) } \\
\hline Manure (M) & $\mathbf{F}_{\mathbf{1}}$ & $\mathbf{F}_{\mathbf{2}}$ & $\mathbf{F}_{\mathbf{3}}$ \\
\hline $\mathrm{M}_{1}$ & 25.25 & 46.50 & 52.89 \\
\hline $\mathrm{M}_{2}$ & 70.68 & 129.51 & 135.81 \\
\hline S.Em. \pm & \multicolumn{3}{|c}{3.82} \\
\hline C.D. at 5\% & \multicolumn{3}{|c}{11.21} \\
\hline
\end{tabular}

Table 11: Interaction effects on total $N$ uptake by grain and straw of pearlmillet

\begin{tabular}{|c|c|c|c|c|c|}
\hline \multirow{2}{*}{ Treatments } & \multicolumn{5}{|c|}{ Total N uptake by grain and straw (kg/ha) } \\
\cline { 2 - 6 } & \multicolumn{3}{|c|}{ Fertilizer (F) } & Biofertilizer (B) \\
\hline Manure (M) & $\mathbf{F}_{\mathbf{1}}$ & $\mathbf{F}_{\mathbf{2}}$ & $\mathbf{F}_{\mathbf{3}}$ & $\mathbf{B}_{\mathbf{1}}$ & $\mathbf{B}_{\mathbf{2}}$ \\
\hline $\mathrm{M}_{1}$ & 39.59 & 72.54 & 78.56 & 56.97 & 70.16 \\
\hline $\mathrm{M}_{2}$ & 114.69 & 186.75 & 197.99 & 151.71 & 181.24 \\
\hline S.Em. \pm & \multicolumn{3}{|c|}{3.87} & \multicolumn{3}{c|}{3.16} \\
\hline C.D. at 5\% & \multicolumn{3}{|c|}{11.35} & \multicolumn{2}{c}{9.27} \\
\hline
\end{tabular}

Table 12: Interaction effects on total $\mathrm{P}_{2} \mathrm{O}_{5}$ uptake by grain and straw of pearlmillet

\begin{tabular}{|c|c|c|c|c|c|}
\hline \multirow{2}{*}{ Treatments } & \multicolumn{5}{|c|}{ Total $\mathbf{P}_{\mathbf{2}} \mathbf{O}_{5}$ uptake by grain and straw (kg/ha) } \\
\cline { 2 - 6 } & \multicolumn{3}{|c|}{ Fertilizer (F) } & \multicolumn{1}{c|}{ Biofertilizer (B) } \\
\hline Manure (M) & $\mathbf{F}_{\mathbf{1}}$ & $\mathbf{F}_{\mathbf{2}}$ & $\mathbf{F}_{\mathbf{3}}$ & $\mathbf{B}_{\mathbf{1}}$ & $\mathbf{B}_{\mathbf{2}}$ \\
\hline $\mathrm{M}_{1}$ & 7.46 & 14.88 & 16.71 & 11.04 & 14.99 \\
\hline $\mathrm{M}_{2}$ & 24.11 & 40.68 & 45.24 & 31.96 & 41.39 \\
\hline S.Em. \pm & \multicolumn{3}{|c|}{1.02} & \multicolumn{2}{c|}{0.83} \\
\hline C.D. at 5\% & 2.98 & \multicolumn{2}{c}{2.43} \\
\hline
\end{tabular}

Table 13: Interaction effects on total $\mathrm{K}_{2} \mathrm{O}$ uptake by grain and straw of pearlmillet

\begin{tabular}{|c|c|c|c|c|c|}
\hline \multirow{2}{*}{ Treatments } & \multicolumn{5}{|c|}{ Total $\mathbf{K}_{\mathbf{2}} \mathbf{O}$ uptake by grain and straw (kg/ha) } \\
\cline { 2 - 6 } & \multicolumn{3}{|c|}{ Fertilizer (F) } & Biofertilizer (B) \\
\hline Manure (M) & $\mathbf{F}_{\mathbf{1}}$ & $\mathbf{F}_{\mathbf{2}}$ & $\mathbf{F}_{\mathbf{3}}$ & $\mathbf{B}_{\mathbf{1}}$ & $\mathbf{B}_{\mathbf{2}}$ \\
\hline $\mathrm{M}_{1}$ & 32.49 & 60.63 & 69.69 & 48.41 & 60.14 \\
\hline $\mathrm{M}_{2}$ & 92.75 & 166.89 & 176.04 & 132.02 & 158.44 \\
\hline S.Em. \pm & \multicolumn{3}{|c|}{4.11} & \multicolumn{2}{c|}{3.36} \\
\hline C.D. at 5\% & \multicolumn{3}{|c|}{12.05} & .84 \\
\hline
\end{tabular}

Table 14: Interaction effects on protein yield of pearlmillet

\begin{tabular}{|c|c|c|c|c|c|}
\hline \multirow{2}{*}{ Treatments } & \multicolumn{4}{|c|}{ Protein yield (kg/ha) } \\
\cline { 2 - 6 } & \multicolumn{3}{|c|}{ Fertilizer (F) } & \multicolumn{1}{|c|}{ Biofertilizer (B) } \\
\hline Manure (M) & $\mathbf{F}_{\mathbf{1}}$ & $\mathbf{F}_{\mathbf{2}}$ & $\mathbf{F}_{\mathbf{3}}$ & $\mathbf{B}_{\mathbf{1}}$ & $\mathbf{B}_{\mathbf{2}}$ \\
\hline $\mathrm{M}_{1}$ & 134.90 & 253.96 & 277.96 & 197.57 & 246.97 \\
\hline $\mathrm{M}_{2}$ & 392.07 & 651.72 & 694.78 & 522.13 & 636.91 \\
\hline S.Em. \pm & \multicolumn{3}{|c|}{14.31} & \multicolumn{2}{c|}{11.65} \\
\hline C.D. at 5\% & \multicolumn{3}{|c|}{41.96} & \multicolumn{2}{c}{34.26} \\
\hline
\end{tabular}

\section{References}

1. Anonymous. Area and production of pearl millet in India. Agricultural Statistics, Directorate of Economics and Statistics, Govt. of India, 2011.

2. Bhalerao GA, Hamid A, Bipte AR. Effect of integrated nutrient management with vermicompost on growth and yield of rainfed sorghum. Annals of Plant Physiology. 2002; 15(2):121-125.

3. Chandra P, Singh J P, Panwar CS. Effect of fertility levels and plant population on leaf area productivity and quality of pearlmi llet hybrid under dry land condition. Environment \& Ecology. 2014; 32(2):702-704.

4. Duhan, BS. Effect of integrated nutrient management on yield and nutrient uptake by sorghum (Sorghum bicolour L.). Forage Research. 2013; 39(3):156-158.

5. Gangwar KS, Niranjan KP. Effect of organic manures and inorganic fertilizers on sorghum (Sorghum bicolar). Indian Journal of Agricultural Science. 1991; 61(2):193194.

6. Jadhav RP, Khafi HR, Raj AD. Effect of nitrogen and vermicompost on protein content and nutrients uptake in pearlmillet (Pennisetum glaucum (L.) R. Br. Emend stuntz.). Agricultural Science Digest. 2011; 31(4):319321.

7. Jain AK, Shrivastava S, Arya V. Response of organic manure, zinc and iron on soil properties, yield and nutrient uptake by pearlmillet crop grown in Inceptisol. International Journal of Pure and Applied Bioscience. 2018; 6(1):426-435.

8. Kathuria MK, Singh Habir, Singh K P, Kadian VS. Effect of intergrated nutrient management on fodder and nutrient uptake by Kharif fodder under cereal fodderwheat cropping system. Haryana Journal of Agronomy. 2003; 19(1):83-86.

9. Kumawat PD, Jat NL. Effect of organic manure and nitrogen fertilization on productivity of barley. Indian Journal of Agronomy. 2005; 50:200-202.

10. Lattief EA. Growth and fodder yield of forage pearl millet in newly cultivated land as affected by date of planting and integration use of mineral and organic fertilizer. Asian Journal of Crop Science. 2011; 3:35-42.

11. Nanda SS, Alim MA, Santra GH, Dash B. Biofertilizer use in economizing nitrogen in fodder sorghum (Sorghum bicolor L.). Environment and Ecology. 2001; 19(1):5-8.

12. Narolia RS, Poonia BL Growth dynamics, yield and economics of pearl millet (Pennisetum glaucum) as influenced by vermicompost and fertilizers. Annals of Arid Zone. 2011; 50(2):145-149.

13. Panse VG, Sukhatme PV. Statistical Method for Agricultural workers, I. C. A. R., New Delhi, 1985.

14. Rathore VS, Singh P, Gautam RC. Productivity and water-use efficiency of rainfed pearlmillet (Pennisetum glaucum) as influenced by planting patterns and integrated nutrient management. Indian Journal of Agronomy. 2006; 51(1):46-48. 
15. Shrivastava S, Arya V. Effect of integrated application of inorganic and organic sources of manures on test weight, length of earhead and available soil micronutrient under pearlmillet crop. International Journal of Pure and Applied Bioscience. 2017; 5(5):720-724.

16. Suke SN, Deotale RD, Priyanka H, Deogirkar M, Sorte $\mathrm{NV}$. Effect of nutrients and biofertilizer of chemical and biochemical parameters of maize (Zea mays L.). Journal of Soils and Crops. 2011; 21:107-112.

17. Togas R, Yadav LR, Choudhary SL, Shisuvinahalli GV. Effect of Azotobacter on growth, yield and quality of pearlmillet. Journal of Pharmacognosy and Phytochemistry. 2015; 6(4):889-891.

18. Tripathi AK, Kushwaha HS. Performance of pearlmillet (Pennisetum glaucum) intercoppped with pigeonpea (Cajanus cajan) under varying fertility levels in the rainfed environment of Bundelkhand region. Annals of Agricultural Research. 2013; 34(1):36-43.

19. Vandana SS, Pahuja SK, Thakral L, Kumar A. Nutrient content and their uptake in hybrid pearl millet as affected by organic and inorganic fertilizers. Haryana Journal of Agronomy. 2008; 1-2:88-89.

20. Vidyadharan, Veena. Integrated nutrient management in barley. Ph.D. Thesis, Rajasthan Agriculture University, Bikaner, 2008.

21. Wani SP, Chandrapalaih S, Zambre MA, Lee KK. Association between nitrogen fixing bacteria and pearlmillet. Plant and Soil. 1988; 110 (2):289-302. 